НАУКОВИЙ ВІСНИКК (1) and

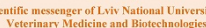

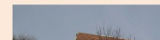

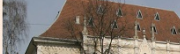
11) MIMMN

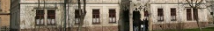

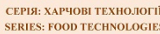
Том 23 № 96 2021
Науковий вісник Дьвівського національного університету ветеринарної медицини та біотехнодогій імені С.3. Гжицького. Серія: Харчові технології

\section{Scientific Messenger of Lviv National University} of Veterinary Medicine and Biotechnologies.

Series: Food Technologies

https://nvlvet.com.ua/index.php/food

UDC 664.3:665.325.2

\title{
Organoleptic characteristics and nutritional value of roasted peanuts from the chain of hotel and restaurant complexes in Kiev region
}

\author{
L. Korol-Bezpala, S. Merzlov, V. Marshalok, H. Merzlova, Y. Shurchkova, H. Kalinina, O. Hrebelnyk
}

Bila Tserkva National Agrarian University, Bila Tserkva, Ukraine

Article info

Received 05.04.2021

Received in revised form 10.05.2021

Accepted 11.05.2021

Bila Tserkva National Agrarian University, Pl. Soborna 8/1, Bila Tserkva, 09117, Ukraine. Tel. : +38-098-551-42-50 E-mail:lesy25@ukr.net
Korol-Bezpala, L., Merzlov, S., Marshalok, V., Merzlova, H., Shurchkova, Y., Kalinina, H., \& Hrebelnyk, $O$. (2021). Organoleptic characteristics and nutritional value of roasted peanuts from the chain of hotel and restaurant complexes in Kiev region. Scientific Messenger of Lviv National University of Veterinary Medicine and Biotechnologies. Series: Food Technologies, 23(96), 15-18. doi: $10.32718 /$ nvlvet-f9603

Foods must contain all the nutrients necessary to maintain human health, development and life. These components include protein, fats, carbohydrates, vitamins, minerals and other biologically active substances, which must be in sufficient quantity and ensure the proper functioning of the body. One such food that contains significant amounts of nutrients is peanuts. Peanuts are a source of protein, carbohydrates, fats, fiber, trace elements and vitamins. The nutrients of the product are easily absorbed. The article presents the results of a study of the nutritional value of roasted salted peanuts of various manufacturers, which are used for consumption in hotel and restaurant complexes in the Kiev region. The studies were carried out in the laboratory of the State Research Control Institute of Veterinary Drugs and Feed Additives (Lviv). Nutritional value was determined according to different methods, which are intended for each indicator, and also used statistical methods. According to the research results, it was revealed that the content of moisture, protein, fat and fiber in peanuts Big Bo, Felix Peanuts and Cossack Slava ranges, respectively, in the range from 0.73 to $1.37 \%$, from 26.3 to 26.9 , from 46.01 to $48.6 \mathrm{~g} / 100 \mathrm{~g}$ of product and 3.56 to $3.92 \%$. According to organoleptic parameters, prototypes of peanuts from different manufacturers meet the standard requirements. Promising research is the study of trace elements in roasted salted peanuts from various manufacturers.

Key words: food products, moisture, protein, fat, ash, fiber, carbohydrates, energy value.

\section{Органолептичні показники та харчова цінність арахісу смаженого із мережі готельно-рестораних комплексів Київщини}

Л. П. Король-Безпала, С. В. Мерзлов, В. А. Маршалок, Г. В. Мерзлова, Ю. О. Шурчкова, Г. П. Калініна, О. П. Гребельник

Білочерківський національний аграрний університет, м Біла Церква, Украӥна

\footnotetext{
Харчові продукти мають містити усі поживні речовини, необхідні для підтримання здоров'я, розвитку та життєдіяльності людини. До таких компонентів належать протеӥн, жири, вуглеводи, вітаміни, мінеральні речовини та інші біологічно активні речовини, які повинні бути в достатній кількість та забезпечувати належне функиіонування організму. Одним із таких харчових продуктів, який містить значну кількість поживних речовин є арахіс. Арахіс є джерелом білка, вуглеводів, жирів, клітковини, мікроелементів та вітамінів. Поживні речовини продукту легко засвоюються. У статті представлені результати дослідження поживної иінності арахісу смаженого солоного різних виробників, які використовують для вживання в готельно-рестораних комплексах Київщини. Дослідження проводили в умовах лабораторії Державного науково-дослідного контрольного інституту ветпрепаратів та кормових добавок (м. Львів). Поживну иінність визначали за різними методиками, які призначені для кожного показника, а також використовували статистичні методики. За результатами досліджень виявлено, що вміст вологи, білка, жиру та клітковини у арахісах Big Вов, Felix Peanuts та Козачька Слава коливається, відповідно, в межах від 0,73 до 1,37 \%, від 26,3 до 26,9, від 46,01 до 48,6 г/100 г продукту та від 3,56 до 3,92\%. За органолептичними показниками дослідні зразки арахісу
} 
різних виробників відповідають стандартним вимогам. Перспективними дослідженнями є вивчення мікроелементів в арахісі жареному солоному різних виробників.

Ключові слова: харчові продукти, волога, білок, жир, зола, клітковина, вуглеводи, енергетична цінність.

Вступ

Збалансоване харчування є однією 3 найактуальніших проблем людства нашого тисячоліття. Сьогодні у більшості населення планети виявляється незбалансованість раціонів за білками, вітамінами, мінеральними речовинами, поліненасиченими жирними кислотами та іншими нутрієнтами (Hachak et al., 2020; 2021).

Одними із харчових продуктів, які насичені різними поживними речовинами, необхідними для організму, є горіхоплідні. Їхні поживні можливості ще не повною мірою розкриті. Вони застосовуються як в харчуванні так і в промисловому виробництві (Zubar, 2010; Dubinina et al., 2017).

Представником горіхоплідних $є$ арахіс, який дуже цінний в першу чергу завдяки вмісту жирів у яких велика кількість ненасичених кислот. Тому, цей горіх $\epsilon$ важливим продуктом у боротьбі з багатьма захворюваннями: серцево-судинних, інсульти, неврози, депресії, фізичне виснаження, також корисний за діабету оскільки контролює цукор у крові (Settaluri et al., 2012).

За поживною цінністю арахіс підходить як вегетаріанцям так і любителям м'ясної продукції, забезпечуючи при цьому організм великою кількістю вітамінів, мінералів та амінокислот (Zolotukhina, 2017).

Apaxic (Arachis) - дуже поширена однорічна невисока трав'яниста культура родини бобових, вона відрізняється від інших представників сімейства бобових за своєю біологічною особливістю. Арахіс, або земляний горіх, відрізняється однією особливістю. Після його запилення відбувається перетворення в гінофор (плодоносний пагін), який на перших стадіях розвит- ку росте вгору, а потім міняє напрямок росту вниз, в грунт, де пізніше розвивається і формується плід (Simakhina \& Ukrainets, 2010; Dubinina et al., 2017; Romanova et al., 2021).

Арахіс має високу поживну цінність, яка безпосередньо пов'язана з високим рівнем білків (25,8 \%), жирів (46 \%), вуглеводів (10,1 \%), містить велику кількість вітамінів різних груп та мінеральних речовин, які легко засвоюються в організмі, та задовільняють фізіологічні потреби людини в поживних речовинах та енергетичній цінності (Satina et al., 2011; Dubinina et al., 2017).

Арахіс використовують у свіжому, смаженому, солоному та вкритому солодкою глазур'ю вигляді. Горіхи застосовують за виробництва олії, в кондитерських виробах, косметології, промисловому виробництві, медицині для приготування різних емульсій (Alper \& Mattes, 2003; Vlasenko et al., 2020).

Mета дослідження - встановлення фактичної поживної цінності арахісу смаженого солоного, різних виробників, які використовують для споживання в готельно-рестораних комплексах Київщини.

\section{Матеріал і методи досліджень}

Дослідні зразки арахісу були придбані у готельнорестораних комплексах розташованих на трасі КиївОдеса та в м. Біла Церква. Дослідження проводили в умовах лабораторії Державного науково-дослідного контрольного інституту ветпрепаратів та кормових добавок (м. Львів).

Для дослідження брали арахіс сорту Спеніш смажений солоний різних виробників (рис. 1).

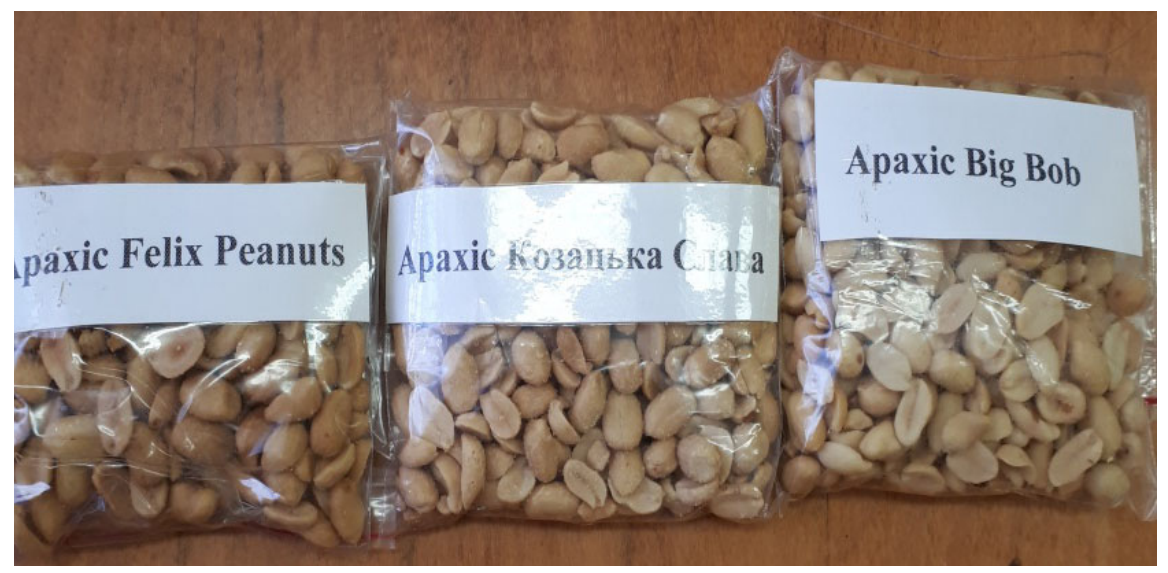

Рис. 1. Дослідні зразки

Вміст вологи та золи визначали гравіметричним методом. Білок методом Кельдаля, визначення жиру проводили в апараті Сокслета. Вміст клітковини методом проміжного фільтрування. Енергетичну цінність і вміст вуглеводів в 100 гр. продукту визначали за допомогою розрахунків (RI 2017; RI 2019).
Органолептичні показники: зовнішній вигляд, смак та запах, твердість визначали за ДСТУ 4504:2005 методом контролювання (DSTU 4504:2005, 2006). 


\section{Результати та їх обговорення}

Дослідження були направленні на встановлення поживної цінності арахісу. Результати досліджень подані в (табл. 1).

Експериментально встановлено, що арахіс смажений має дуже високу харчову цінність. Найбільший вміст вологи виявлений у зразках арахісу Felix Peanuts, який становить $1,37 \%$ від сухої речовини. Також виявлено, що у зразках арахісу Козацька Слава вміст вологи становив 1,20\%, що на 0,17\% менше ніж у apaxicy Felix Peanuts. Встановлено, що вміст вологи apaxicy Big Вов на $0,64 \%(\mathrm{P} \leq 0,05)$ менший ніж у Felix Peanuts.

\section{Таблиця 1}

Поживна цінність арахісу смаженого солоного в 100 г продукту, $\mathrm{M} \pm \mathrm{m}, \mathrm{n}=3$

\begin{tabular}{|c|c|c|c|}
\hline Показники & Apaxic Big Boв & Apaxic Felix Peanuts & Арахіс Козацька Слава \\
\hline Волога, \% & $0,73 \pm 0,008^{*}$ & $1,37 \pm 0,104$ & $1,20 \pm 0,091$ \\
\hline Білок, г & $26,40 \pm 0,557$ & $26,90 \pm 0,633$ & $26,30 \pm 0,733$ \\
\hline Жир, г & $46,30 \pm 2,037$ & $46,01 \pm 1,067$ & $48,60 \pm 2,057$ \\
\hline Зола, \% & $2,67 \pm 0,105$ & $2,44 \pm 0,296$ & $2,83 \pm 0,107$ \\
\hline Клітковина, \% & $3,92 \pm 0,333$ & $3,56 \pm 0,232$ & $3,71 \pm 0,257$ \\
\hline Вуглеводи, г & $23,89 \pm 2,152$ & $23,28 \pm 0,008$ & $21,07 \pm 0,006$ \\
\hline Енергетична цінність, ккал & $617,86 \pm 4,121$ & $614,72 \pm 8,240$ & $626,88 \pm 9,314$ \\
\hline
\end{tabular}

Примітка: *P $\leq 0,05$ - по відношенню до “Арахіс Felix Peanuts" та “Арахіс Козацька Слава"

Уміст білка був найбільший у зразках горіхів фірми Felix Peanuts - 26,90 г, що на 0,5 \% більше показника в арахісі Big Вов. Відносно вмісту білка у продукті Козацька Слава то цей показник був нижчим ніж у Felix Peanuts на 0,6\%.

Дослідження показали, що в арахісі знаходиться великий вміст жиру. Найбільша кількість жиру була у горішках Козацька Слава, цей показник становив 48,60 г. Горішки Big Вов на 4,7 \% мали нижчий вміст жиру у порівняні із арахісом Козацька Слава. Аналогічно на 5,3 \% виявлено нижчий вміст жиру у продуктi Felix Peanuts.

Найвищий вміст золи було виявлено у горішках Козацька Слава порівнюючи із продукцією Big Вов та Felix Peanuts показник був більшим, відповідно, на $0,16 \%$ та $0,39 \%$. Розбіжність у показниках золи може пояснюватись вмістом $\mathrm{NaCl}$ у продукті та регіоном вирощування горіхів.

Вміст клітковини на 100 г продукту був найбільший в зразках apaxicy Big Вов, і становив 3,92 \%.
Показник переважав дані отримані у зразках виробників Felix Peanuts i Козацька Слава, відповідно, $0,36 \%$ та $0,21 \%$.

Вміст вуглеводів у горішках змінювався в залежності від виробника. Найнижчий вміст вуглеводів був у продукті Козацька Слава і становив 21,07 г на 100 г. Порівнюючи із арахісом Big Вов та Felix Peanuts piзниця за вмістом вуглеводів становила, відповідно, $11,8 \%$ та $9,5 \%$.

Експериментально встановлено, що найбільша енергетична цінність була у арахісі смаженому солоному Козацька Слава 626,88 ккал у 100 г продукту. Показник переважав арахіс зразків фірми Big Вов та Felix Peanuts на 1,4 \% i 1,9\%. Підвищений рівень енергії пояснюється високим вмістом жиру у горішках Козацька Слава.

За органолептичними показниками всі зразки відповідали вимогам ДСТУ 4504:2005 “Ядра бобів арахісу" (рис. 2).

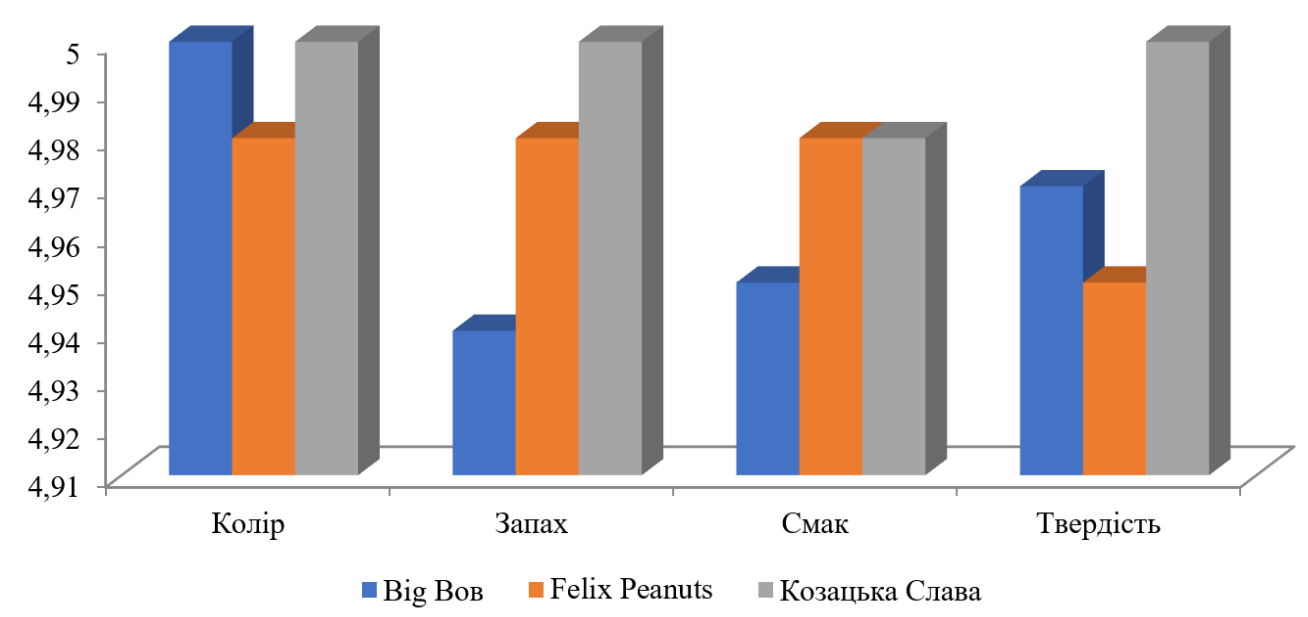

Рис. 2. Показники якості арахісу, бал 
За середньою бальною оцінкою арахіс смажено солоний Big Вов має 4,96 бали, apaxic Felix Peanuts 4,97 бали та продукт Козацька Слава - 4,99 бали.

\section{Висновки}

1. Встановлено, що вміст вологи, білка, жиру та клітковини у горіхах арахісу різних виробників коливається, відповідно, в межах від 0,73 до 1,37 \%, від 26,3 до 26,9, від 46,01 до 48,6 г/100 г продукту та від 3,56 до $3,92 \%$.

2. За органолептичними показниками дослідні зразки арахісу різних виробників відповідають стандартним вимогам.

Перспективи подальших досліджень. Перспективними дослідженнями $\epsilon$ вивчення мікроелементів в aрахісі жареному солоному різних виробників.

\section{References}

Alper, C., \& Mattes, R. (2003). Peanut consumption improves indices of cardiovascular disease risk in healthy adults. J. Am. Coll. Nutri., 22(2), 133-141. doi: 10.1080/07315724.2003.10719286.

DSTU 4504:2005 (2006). Yadra bobiv arakhisu. Zahalni tekhnichni umovy. K.: Derzhspozhyv standart Ukrainy (in Ukrainian).

Dubinina, A. A., Lenert, S. O., Khomenko, O. O., \& Cherevychna, N. I. (2017). Doslidzhennia khimichnoho skladu ta otsinka yakosti sortiv arakhisu, adaptovanykh do vyroshchuvannia v Ukraini: monohrafiia. Elektron. dani. Kh.: KhDUKhT (in Ukrainian).

Hachak, Y., Nagovska, V., Gutyj, B., Mykhaylytska, O., \& Koberniuk, V. (2020). Technological characteristics of processed and prophylactic processed cheese with a new phytospection "Ukrainska kukhnia". Scientific Messenger of LNU of Veterinary Medicine and Biotechnologies. Series: Food Technologies, 22(93), 67-71. doi: 10.32718/nvlvet-f9312.

Hachak, Y., Nahovska, V., \& Gutyj, B. (2021). The use of cryopowder from seafood in the technology of thermostatic yogurt for therapeutic and prophylactic purposes. Scientific Messenger of LNU of Veterinary Medicine and Biotechnologies. Series: Food Technologies, 23(95), 83-90. doi: 10.32718/nvlvet-f9514.

RI 5.4-52/k (2017). Rozrakhunok vuhlevodiv u kormakh (in Ukrainian).

RI 5.4-85/k (2019). Rozrakhunok enerhetychnoi tsinnosti kharchovykh produktiv (in Ukrainian).

Romanova, S. V., Demeshko, O. V., Mykhailenko, O. O., Volochai, V. I., Kozyra, S. A., \& Duchenko, M. A. (2021). Biolohichno aktyvni rechovyny arakhisa kulturnoho. "Planta + Nauka, Praktyka ta osvita" Materialy mizhnarodnoi naukovo-praktychnoi konferentsii. Kyiv, 165-169. URL: http://dspace.nuph.edu.ua/handle/ 123456789/24950 (in Ukrainian).

Satina, H. M., Oleshchenko, F. H., Koshlakova, N. M. ta in. (2011). Naukovi osnovy ta skladovi haluzevoi prohramy rozvytku horikhivnytstva $\mathrm{v}$ Ukraini. Kyiv: Lohos (in Ukrainian).

Settaluri V. S., Kandala, C. V. K., Puppala, N., \& Sundaram, J. (2012). Peanuts and Their Nutritional Aspects - A Review. Food and Nutrition Sciences, 3(2), 25267. doi: 10.4236/fns.2012.312215.

Simakhina, H. O., \& Ukrainets, A. I. (2010). Innovatsiini tekhnolohii ta produkty: ozdorovche kharchuvannia. K.: NUKhT (in Ukrainian).

Vlasenko, N. M., Romanova, S. V., Kozyra, S. A., \& Volochai, V. I. (2020). Khimichnyi sklad arakhisa kulturnoho. Materialy IV Mizhnarodnoi naukovopraktychnoi internet-konferentsii. Kharkiv, 69. URL: https://dspace.nuph.edu.ua/bitstream/123456789/2404 0/1/69.pdf (in Ukrainian).

Zolotukhina, I. V. (2017). Konspekt lektsii z kursu "Innovatsiini restoranni tekhnolohii" (dlia studentiv 5 kursu dennoi formy navchannia osvitnokvalifikatsiinoho rivnia mahistr, spetsialnosti 241 - Hotelna i restoranna sprava).Kharkiv. nats. un-t misk. hosp-va im. O. M. Beketova. Kharkiv: KhNUMH im. O. M. Beketova (in Ukrainian).

Zubar, N. M. (2010). Osnovy fiziolohii ta hihiieny kharchuvannia: Pidruchnyk. K.: Tsentr uchbovoi literatury (in Ukrainian). 